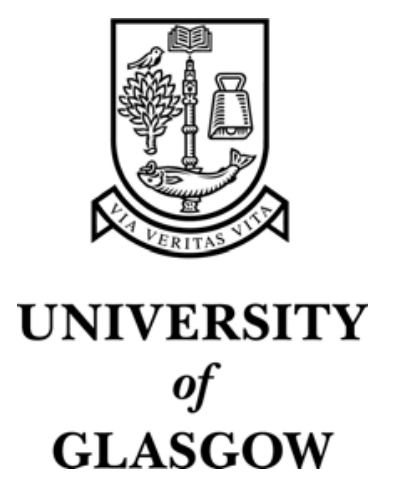

Cohen, B. L. and Balfe, P. and Cohen, M. and Curry, G. B. (1993)

Molecular and morphometric variation in European populations of the articulate brachiopod Terebeatulina retusa. Marine Biology 115(1):pp. 105-111.

http://eprints.gla.ac.uk/2945/ 


\title{
Molecular and morphometric variation in European populations of the articulate brachiopod Terebratulina retusa
}

\author{
B. L. Cohen ${ }^{1}$, P. Balfe ${ }^{1}$, M. Cohen ${ }^{1}$, G. B. Curry ${ }^{2}$ \\ ${ }_{1}^{1}$ Department of Genetics, University of Glasgow, Glasgow G11 5JS, Scotland \\ 2 Department of Geology and Applied Geology, University of Glasgow, Glasgow G12 8QQ, Scotland
}

Received: 13 May 1992 / Accepted: 13 August 1992

\begin{abstract}
Molecular and morphometric variation within and between population samples of the articulate brachiopod Terebratulina spp., collected in 1985-1987 from a Norwegian fjord, sea-lochs and coastal sites in western Scotland, the southern English Channel (Brittany) and the western Mediterranean, were measured by the analysis of variation in the lengths of mitochondrial DNA (mtDNA) fragments produced by digestion with nine restriction endonucleases and by multivariate statistical analysis of six selected morphometric parameters. Nucleotide difference within each population sample was high. Nucleotide difference between population samples from the Scottish sites, both those that are tidally contiguous and those that appear to be geographically isolated, were not significantly different from zero. Nucleotide differences between the population samples from Norway, Brittany, Scotland and the western Mediterranean were also very low. Morphometric analysis confirmed the absence of substantial differentiation.
\end{abstract}

\section{Introduction}

Articulate brachiopods have short-lived, lecithotrophic larvae, a property that "should lead readily to spatial, reproductive and hence genetic isolation between ... populations ... the conditions under which speciation is most likely" (Rudwick 1970, see also Valentine and Jablonski 1983). This "divergence" hypothesis has never been tested by the study of genetic variability in geographically dispersed populations of articulate brachiopods. Accounts of genetic variability are limited to descriptions of allozyme variation in geographically undifferentiated deep-sea samples of Freileia halli, Liothyrella notorcadensis and Coptothyris grayi (Ayala et al. 1975, Valentine and Ayala 1975, Balakirev and Manchenko 1985) or of morphometric and molecular divergence between eastern and western North Atlantic morphospecies of Terebratulina, $T$. retusa and $T$. septentrionalis (Cohen et al. 1991). In the course of the latter study, we obtained population samples of the eastern Atlantic form, T. retusa, drawn from sites as far apart as Norway and the western Mediterranean, and this communication reports the results of analyses of these specimens for mitochondrial DNA (mtDNA) restriction-fragment length polymorphism (RFLP) and for variation in morphometric parameters of the shell.

For Terebratulina spp., the expectations of the divergence hypothesis are based on empirical and anecdotal evidence that larvae settle within 1 wk (Morse 1873, Noble et al. 1976, Webb et al. 1976). Support for the expectation that RFLP analysis of mtDNA would be capable of revealing such differentiation can be drawn from examples in which oceanographic or life-history factors provide mechanisms of isolation and where, using this methodology, $2 \%$ or more nucleotide divergence has been revealed between populations of marine organisms that are somewhat more vagile than articulate brachiopods (e.g. Avise et al. 1986, Baker et al. 1990, Reeb and Avise 1990). In contrast, and as expected, little or no divergence was found between highly vagile marine organisms (e.g. Graves et al. 1984, Wirgin et al. 1989).

\section{Materials and methods}

The numbers of individual specimens and geographic origins of the population samples of Terebratulina retusa are given in Table 1. Specimens from Tromsø, Firth of Lorne, Sound of Mull and the western Mediterranean were collected by dredge. All other specimens were hand-picked by SCUBA divers. The Scottish divers were requested to include all macroscopic articulate brachiopods from one or a few small areas of rock substrate. In practice, most divercollected individuals were at least $1.0 \mathrm{~cm}$ long. Amongst dredged samples, individuals $\leq 0.6 \mathrm{~cm}$, if collected, were not analysed. Thus, the analysis was restricted to brachiopods older than $\sim 1$ to $2 \mathrm{yr}$ (Curry 1982). The Tromsø sample was suitable only for morphometric analysis.

Whilst most specimens were collected from closely circumscribed localities, those from the Mediterranean came from three separate collection sites. However, these sites are considered to be within the dispersal range of larvae (C. C. Emig personal communication 1990) and are closer together than the most distant pair of 
Table 1. Terebratulina retusa. Geographical origin of population samples and specimen numbers analysed. Each population sample treated as a single operational taxonomic unit (OTU), except those indicated by asterisk, which constituted the OTU "Oban" (see "Results and discussion - mtDNA analysis")

\begin{tabular}{|c|c|c|c|}
\hline \multirow[t]{2}{*}{$\begin{array}{l}\text { Region } \\
\text { Sampling-site }\end{array}$} & \multirow[t]{2}{*}{ Longitude; Latitude } & \multicolumn{2}{|c|}{$\begin{array}{l}\text { Numbers analysed } \\
\text { for: }\end{array}$} \\
\hline & & mtDNA & $\begin{array}{l}\text { morpho- } \\
\text { metrics }\end{array}$ \\
\hline \multicolumn{4}{|l|}{ Norway } \\
\hline Dröbak, (Oslo Fjord) & $59^{\prime} 39^{\prime \prime} \mathrm{N} ; 10^{\prime} 48^{\prime \prime} \mathrm{E}$ & 12 & - \\
\hline Tromsø & $69^{\prime} 40^{\prime \prime} \mathrm{N} ; 19^{\prime} 00^{\prime \prime} \mathrm{E}$ & - & 17 \\
\hline \multicolumn{4}{|l|}{ Scotland } \\
\hline Loch Duich & $57^{\prime} 16^{\prime \prime} \mathrm{N} ; 05^{\prime} 31^{\prime \prime} \mathrm{W}$ & 10 & - \\
\hline Sound of Mull & $56^{\prime} 31^{\prime \prime} \mathrm{N} ; 05^{\prime} 52^{\prime \prime} \mathrm{W}$ & $15^{*}$ & 15 \\
\hline Firth of Lorne & $56^{\prime} 24^{\prime \prime} \mathrm{N} ; 05^{\prime} 33^{\prime \prime} \mathrm{W}$ & $19^{*}$ & 11 \\
\hline $\begin{array}{c}\text { Luing (Balnahua, } \\
\text { Culnach and } \\
\text { Garvellachs) }\end{array}$ & $56^{\prime} 16^{\prime \prime} \mathrm{N} ; 05^{\prime} 39^{\prime \prime} \mathrm{W}$ & $14^{*}$ & - \\
\hline Insh Island & $56^{\prime} 18^{\prime \prime} \mathrm{N} ; 05^{\prime} 39^{\prime \prime} \mathrm{W}$ & $18^{*}$ & - \\
\hline Sound of Jura & $56^{\prime} 05^{\prime \prime} \mathrm{N} ; 05^{\prime} 35^{\prime \prime} \mathrm{W}$ & $19 *$ & - \\
\hline Loch Fyne (Kenmore) & $56^{\prime} 15^{\prime \prime} \mathrm{N} ; 05^{\prime} 59^{\prime \prime} \mathrm{W}$ & 16 & 21 \\
\hline \multicolumn{4}{|l|}{ Brittany (France) } \\
\hline Isle de Batz (Roscoff) & $48^{\prime} 44^{\prime \prime} \mathrm{N} ; 04^{\prime} 04^{\prime \prime} \mathrm{W}$ & 23 & 6 \\
\hline \multicolumn{4}{|l|}{ Western Mediterranean } \\
\hline Calvi (Corsica) & $42^{\prime} 42^{\prime \prime} \mathrm{N} ; 08^{\prime} 75^{\prime \prime} \mathrm{E}$ & & \\
\hline Isles d'Hyères & $\left.42^{\prime} 58^{\prime \prime} \mathrm{N} ; 06^{\prime} 24^{\prime \prime} \mathrm{E}\right\}$ & 20 & 20 \\
\hline La Çiotat & $\left.42^{\prime} 59^{\prime \prime} \mathrm{N} ; 05^{\prime} 33^{\prime \prime} \mathrm{E}\right\}$ & & \\
\hline
\end{tabular}

Scottish sites. The Mediterranean specimens will therefore be treated as a single operational taxonomic unit (OTU).

Molecular and morphometric methods are described elsewhere in full (Cohen et al. 1991). Briefly, to estimate the nucleotide difference between mitochondrial DNA sequences, aliquots of total DNA were digested with nine informative restriction enzymes (AccI, AvaI, AvaII, BglII, DraI, EcoRV, PstI, PvuII, SstI) and restriction fragments ( $>0.5$ kbase pairs) were detected by agarose gel electrophoresis and capillary transfer to nylon membrane followed by hybridization with a radioactively-labelled, cloned, homologous mtDNA probe and autoradiography. The probe was a 15.8 to 16.5 kbase pair insert of quasi-complete Terebratulina retusa mtDNA in a lambda phage. Genetic distance (as nucleotide difference, $\hat{d}$, corrected for within-population divergence) was estimated from the frequencies of shared fragments and standard errors were obtained by 200 bootstrap cycles using the RESTSITE programs (Miller 1991). Since not more than 20 out of $179(11 \%)$ restriction sites were mapped, $\hat{d}$ was estimated by the iteration procedure for unmapped fragments (Nei 1987: Eq. 5.54). We will refer to these estimates as $\hat{d}_{f}$. Nucleotide difference $\left(\hat{d}_{s}\right)$ was also calculated by the "site" procedure (Nei and Li 1979, Nei and Miller 1990: Eq. 17) and both $\hat{d}_{f}$ and $\hat{d}_{s}$ values will generally be quoted in the expectation that the best estimate is intermediate. However, the restriction endonucleases used did not constitute a random sample; enzymes yielding $<3$ fragments in common mitotypes were considered uninformative and were not used. Thus, as is common in many such studies, $\hat{d}$ values are biased upwards. Cluster analysis of genetic distances was carried out by the UPGMA (unweighted pair group mean of analysis) procedure (Sokal and Michener 1958) using a program from the RESTSITE package, on the assumption that evolutionary rates in different lineages would be uniform. For morphometric analyses, six morphometric parameters, pre-selected by principal components analysis (PCA) to give maximum discrimination between brachiopod morphospecies, were measured by standard techniques. The parameters were: maximum length, width and height of con- joined valves, number of ribs in a $5 \mathrm{~mm}$ sector $10 \mathrm{~mm}$ anterior of the brachial valve umbo, lateral width of the pedicle foramen, and anterior-posterior width of the pedicle foramen. The data were analysed by standard statistical procedures including PCA.

\section{Results and discussion}

mtDNA analysis

Results with all nine restriction endonucleases were obtained on DNAs from 109 individuals of Terebratulina retusa, amongst which 84 different nine-enzyme haplotypes ("mitotypes") were identified. These mitotypes and their geographic distribution are given in Table 2. Results with 5 to 8 enzymes were obtained on a further 57 individuals, so that the total number of individuals analysed was 166. The number of different restriction fragments identified was 170 and the average number of fragments per individual was $\sim 42$. Thus, $\sim 240$ bp $(1.5 \%)$ of the mitochondrial genome was screened for variation. The relatively low resolution of this analysis was dictated by limiting yields of DNA, reflecting the low biomass of the smaller individuals of $T$. retusa. The average nucleotide difference between all pairs of individuals $(n=166)$ was $d_{f}=0.0212 \pm 0.0067, d_{s}=0.0577 \pm 0.0170$.

Length variation greater than $\sim 150 \mathrm{bp}$ was not detected in the mtDNA of Terebratulina retusa using both a sensitive test with an internal standard and cross-comparison of digests, whereas such variation was ubiquitous in the western Atlantic morphospecies $T$. septentrionalis. All variants were therefore treated as changes in restriction sites and included in the analysis. Heteroplasmy was also not detected in T. retusa although it was found in $T$. septentrionalis (Cohen et al. 1991).

\section{mtDNA diversity in Terebratulina retusa}

Nucleon (haplotype) diversity was calculated from the frequencies of the 84 different mitochondrial haplotypes recognized amongst the 109 individuals that were analysed successfully with all 9 restriction enzymes (Table 2 ). The resulting value was $\hat{h}=0.9886$. Similar high values were obtained in each population sample except that from Dröbak, where $\hat{h}=0.85$ (see legend to Table 3 ). The geographic distribution of the mitotypes is given in Table 2.

Haplotype diversity values as high as 0.99 have rarely been observed in other organisms and have been given special attention because of the possibility of characterising individuals by their mitotype ("fingerprinting", Avise et al. 1989). In Terebratulina retusa, these high values were obtained with a relatively small number of restriction digests. With a more sensitive assay (Wilson et al. 1985), almost every individual would be readily distinguishable. Thus, haplotype diversity assays are somewhat artificial, being strongly affected by the number of restriction endonucleases used and the extent to which they are selected for informativeness. Nevertheless, it is clear that many organisms (especially vertebrates) show far 
Table 2. Terebratulina retusa. Geographic distribution of nine-enzyme mitotypes amongst OTUs (see Table 1). mtDNA morphs recognized for each enzyme are identified alphabetically, but for restriction enzyme AvaII, more than 26 morphs were identified and those following " $Z$ " are identified by numbers. Mitotypes are arranged from the left to right in alphabetical order of restriction enzymes, AccI, AvaI, AvaII, BglII, DraI, EcoR V, PstI, PvuII, SstI. Hence, mitotype "AAAABCAAD" indicates presence of "A" morphs for AccI, AvaI, AvaII and BgIII, "B" morph for DraI, "C" morph for EcoRV, etc. Note that there are no entries in this Table for individuals from Dröbak OTU, from which only incomplete, 5to 8 -enzyme mitotypes were obtained

\begin{tabular}{|c|c|c|c|c|c|c|}
\hline \multirow[t]{2}{*}{ Mitotype } & \multicolumn{6}{|l|}{ OTU } \\
\hline & $\begin{array}{l}\text { Loch } \\
\text { Duich }\end{array}$ & "Oban" & $\begin{array}{l}\text { Loch } \\
\text { Fyne }\end{array}$ & $\begin{array}{l}\text { Isle de } \\
\text { Batz }\end{array}$ & $\begin{array}{l}\text { Medi- } \\
\text { terra- } \\
\text { nean }\end{array}$ & Total \\
\hline AAAABCAAD & & 1 & & & & 1 \\
\hline AADAAAAAA & 1 & 1 & & & & 2 \\
\hline AADABAAAA & & 5 & & & & 5 \\
\hline AADBCAAHA & & & & & 1 & 1 \\
\hline AAEABAAAD & & & 1 & & & 1 \\
\hline AAEABCAAB & 1 & 2 & 1 & 1 & & 5 \\
\hline AAEBCCAAB & & 1 & & & & 1 \\
\hline AAFABAAAD & & 1 & & & & 1 \\
\hline AAGABAAAA & & 1 & & & & 1 \\
\hline AAHABAAAF & & 1 & & & & 1 \\
\hline AAHABCAEG & & & & 1 & & 1 \\
\hline AAIABAAAA & & 1 & & & & 1 \\
\hline AAUAAAAAA & & & 1 & & & 1 \\
\hline AAWABBAAA & & 1 & & & & 1 \\
\hline AA2AHAAAA & . & & & & 1 & 1 \\
\hline AA3ABAAAF & & & & & & 1 \\
\hline AA7ABCAAG & 1 & & & & & 1 \\
\hline AA9IBCAAA & & & 1 & & & 1 \\
\hline ABAABAAAA & & 1 & & & & 1 \\
\hline ABDABAAAA & & 1 & & & & 1 \\
\hline ABDABAAAB & & 1 & & & & 1 \\
\hline ABDABAAAF & & 1 & & & & 1 \\
\hline ABIAAAAAA & & 1 & & & & 1 \\
\hline ABIABAAAA & 1 & 4 & 2 & 2 & & 9 \\
\hline ABIABAAAE & & 1 & & & & 1 \\
\hline ABIABAAAF & & 2 & & & & 2 \\
\hline ABIABAAAG & & 1 & & & & 1 \\
\hline ABIABAACA & & 1 & & & & 1 \\
\hline ABIABAACF & & 1 & & & & 1 \\
\hline ABIABCACA & & 1 & 1 & & & 2 \\
\hline ABIACAAAA & & 1 & & & & \\
\hline ABIACAACF & & & & 1 & & 1 \\
\hline ABIACAAGA & & 1 & & & & 1 \\
\hline ABIACCAAA & & & & 1 & & 1 \\
\hline ABIAEAAAA & & 1 & & & & 1 \\
\hline ABIAHAAAA & & 1 & & 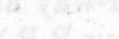 & & 1 \\
\hline ABIBBAAAA & & 3 & & & & 3 \\
\hline АВРАВAAAA & & 1 & & & & 1 \\
\hline ABRABAAAD & & 1 & & & & 1 \\
\hline ABRABAACA & & 1 & & & & 1 \\
\hline ABRACAAAA & & & & 1 & & 1 \\
\hline ABXACAAAA & & & & 1 & & 1 \\
\hline AB6ABAAAA & & 1 & & & & 1 \\
\hline ACDABAABA & & 1 & & & & 1 \\
\hline ACFAAAAAD & & 1 & & & & 1 \\
\hline ACFABAAAD & & & 1 & & & 1 \\
\hline ACHABCAAA & & 1 & & & & 1 \\
\hline ACIABAAAA & & 1 & & & & 1 \\
\hline ACIABAAAF & & 1 & & & & 1 \\
\hline ACVABAOAA & & 1 & & & & 1 \\
\hline $\mathrm{AC} 2 \mathrm{ACAABA}$ & & 1 & & & & 1 \\
\hline AHYABAAAA & 1 & & & & & 1 \\
\hline
\end{tabular}

Table 2 (continued)

\begin{tabular}{|c|c|c|c|c|c|c|}
\hline \multirow[t]{2}{*}{ Mitotype } & \multicolumn{6}{|l|}{ OTU } \\
\hline & $\begin{array}{l}\text { Loch } \\
\text { Duich }\end{array}$ & "Oban" & $\begin{array}{l}\text { Loch } \\
\text { Fyne }\end{array}$ & $\begin{array}{l}\text { Isle de } \\
\text { Batz }\end{array}$ & $\begin{array}{l}\text { Medi- } \\
\text { terra- } \\
\text { nean }\end{array}$ & Total \\
\hline AIDAAAAAA & & & 1 & & & 1 \\
\hline AIDABAAAA & 2 & 1 & & & & 3 \\
\hline AIDMBAAAA & 1 & & & & & 1 \\
\hline AIVAAAAAA & 1 & & & & & 1 \\
\hline AJDABAAAA & & 1 & & & & 1 \\
\hline AJGABCAAA & & 1 & 1 & & $3 \%$ & 2 \\
\hline AJHAACAAD & & 1 & & & & 1 \\
\hline AJKABCAAD & & 1 & & & & 1 \\
\hline AJKEBCAAA & & 1 & & 1 & & 2 \\
\hline AKCABAAAA & & 1 & & & & 1 \\
\hline AKCABAAAD & & 1 & & & & 1 \\
\hline AKIABAAAA & & 1 & & & & 1 \\
\hline ALIAHACAA & & & & 1 & & 1 \\
\hline APDABAAAA & 1 & & & & & 1 \\
\hline ASDAAAAAA & & & & 1 & & 1 \\
\hline BCHABCAAA & & & 1 & & & 1 \\
\hline BCHACAADA & & & & 1 & & 1 \\
\hline BCKABCAAA & & 1 & & & & 1 \\
\hline DDJABCAAA & & & & 1 & & 1 \\
\hline DDOAACAAA & & 1 & & & & 1 \\
\hline DOIKCAACA & & 1 & & & & 1 \\
\hline DQJAACAAA & & 1 & & & & 1 \\
\hline EADABCAAA & & & & & 1 & 1 \\
\hline GADABAAAB & & & & 1 & & 1 \\
\hline GRZDAAAAG & & & & 1 & & 1 \\
\hline HD8NIAAAA & & & 1 & & & 1 \\
\hline IAAABAAAA & & 1 & & & & 1. \\
\hline JBAABAAAA & & 1 & & & & 1 \\
\hline JB5ABAAAD & & & & & 1 & 1 \\
\hline JDPABAAAA & & & & 1 & & 1 \\
\hline LBAAFAAAA & & 1 & & $x^{2}$ & & 1 \\
\hline NCHABCAAA & & 1 & & & & 1 \\
\hline Totals & 10 & 66 & 12 & 16 & 5 & 09 \\
\hline
\end{tabular}

lower levels of diversity than $T$. retusa, such that within any population many individuals possess the same mitotype when analysed using a similar number of enzymes.

High levels of haplotype diversity are reflected by high within-population nucleotide divergences: (mean $\pm \mathrm{SD}$, $n=10) \hat{d}_{f}=0.0182 \pm 0.0042$ (range 0.0105 to 0.0258 ); $\hat{d}_{s}=0.0624 \pm 0.0123$ (range 0.0309 to 0.0757 ). Such diversity may result from a high rate of mtDNA evolution and/or large (stable or expanding) effective population size (Avise et al. 1984). For the reasons given below, we identify large or growing effective population-size as the most important factor in Terebratulina retusa.

The rate of mtDNA evolution in Terebratulina retusa and $T$. septentrionalis can be roughly estimated as follows. We have reported (Cohen et al. 1991) mtDNA nucleotide difference between the western and eastern North Atlantic species $T$. septentrionalis from Canada $(n=40)$ and T. retusa from Scotland $(n=56)$. Recalculated with the procedures used in the present report these values are $\hat{d}_{f}=0.1215 \pm 0.0572, \hat{d}_{s}=0.3493 \pm 0.0760$. If the onset of complete geographic isolation between these species occurred during the opening of the North Atlantic, this level of divergence must have accumulated during some 
$50 \times 10^{6} \mathrm{yr}$, indicating an evolution rate of 0.001 to 0.0035 substitutions per nucleotide per million years per lineage. This very approximate estimate suggests that the rate of mtDNA evolution in these Terebratulina species is not abnormally high, but might be unusually low (Vawter and Brown 1986, Jacobs 1988).

Several lines of evidence indicate that effective population sizes may be large (i.e., considerably greater than $10^{4}$ ). These include: (1) diver's reports (e.g. A. S. G. Curtis personal communication) that the Insh Island, Sound of Jura and Loch Fyne populations, whilst patchy, may reach densities of many hundreds of individuals per square metre over extensive areas, indicative of census sizes of the order of at least $10^{5}$ to $10^{6} ;(2)$ generation time may be extrapolated from data in Curry (1982) to be at least 3 to $5 \mathrm{yr}$; (3) the secondary sex ratio, determined by microscopic observation of gonads, is statistically indistinguishable from 1:1 (BLC and MC unpublished observations); (4) during the breeding season, ripe gonad was present in every individual of the SCUBA-collected samples over a minimum size probably corresponding to the second year class (BLC and MC unpublished observations) and (5) there is no reason to suppose adverse environmental conditions since a marine environment returned to the sites sampled.

Genetic divergence between geographically isolated sampling sites

\section{mtDNA analysis}

Some of the Scottish sampling sites (in north-south order Sound of Mull, Firth of Lorne, Luing, Insh Island and Sound of Jura) were sampled from a contiguous $80 \mathrm{~km}$ stretch of the west coast of Scotland (Fig. 1) where tidal currents are of the order of $1 \mathrm{~m} / \mathrm{s}$ and longshore currents are common (Allen et al. 1986). We therefore anticipated that the brachiopod populations at these sites would not be effectively isolated from one another, except that the Sound of Mull and Firth of Lorne samples, which were dredged from $\sim 200 \mathrm{~m}$, might prove to be isolated (by the thermocline) from the other populations, which were collected by SCUBA divers from depths between $\sim 25$ and $40 \mathrm{~m}$. The results support the expectation of no divergence: none of the pairwise nucleotide differences was significantly different from zero (largest $\hat{d}_{f}=0.0001$ \pm 0.0003 ; largest $\hat{d}_{s}=0.0002 \pm 0.0007$ ). Thus, isolation by the thermocline was not detected. The specimens from all these sites were therefore pooled for further analysis to form a single OTU "Oban".

The remaining two Scottish samples (Loch Duich and Loch Fyne) represent populations from sea-lochs situated respectively $\sim 100 \mathrm{~km}$ north and $\sim 250 \mathrm{~km}$ south and east (by sea) of the "Oban" locality, separated from it by a dissected coastline (Fig. 1) and, at least in the case of Loch Fyne, by tidal streams and land-forms that permit little inter-communication (Allen et al. 1986). They are thus likely to be geographically isolated from the sites of the "Oban" OTU and from one another and are treated separately throughout. Nevertheless, genetic distances

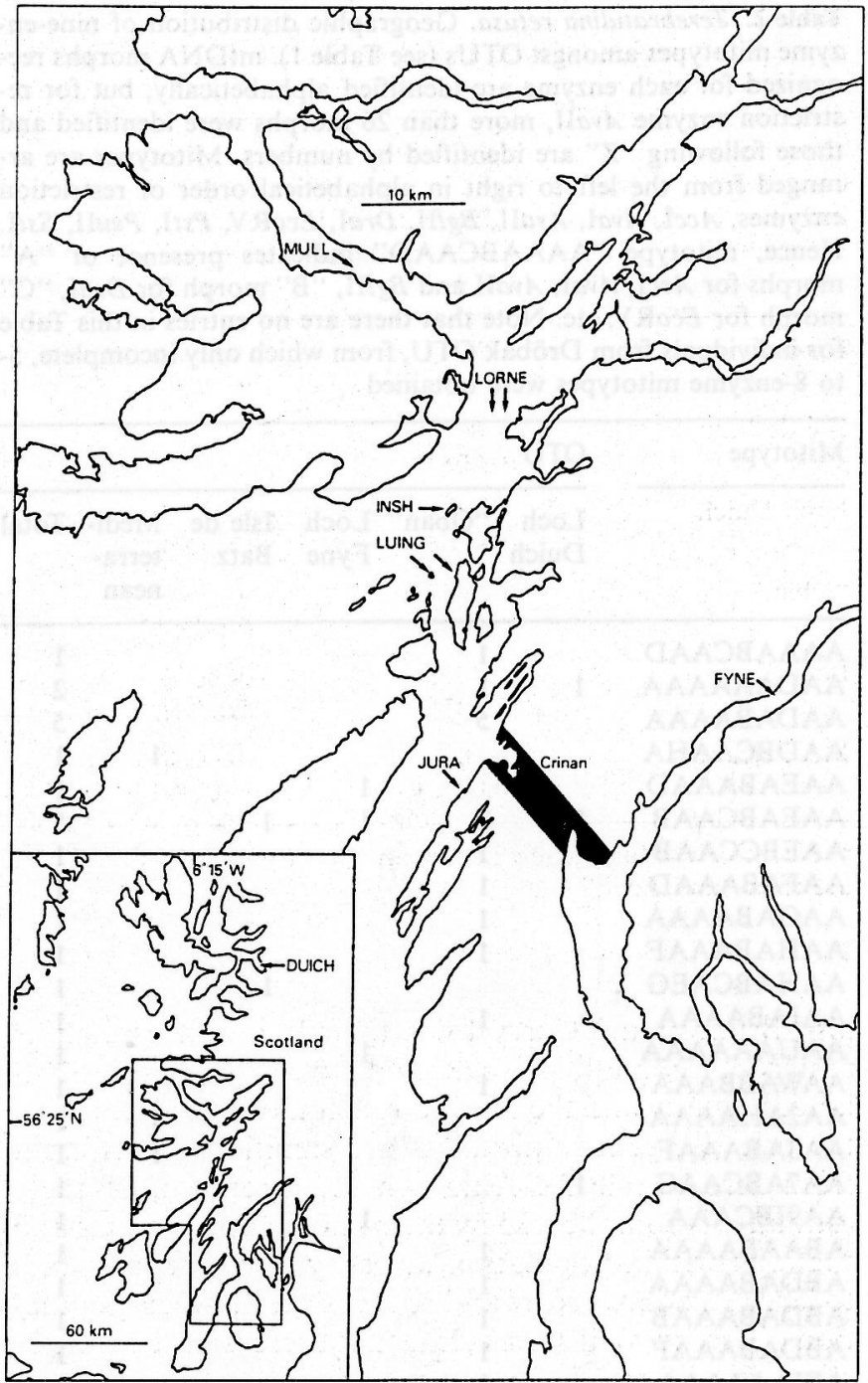

Fig. 1. Scottish collection sites; inset shows small-scale locality-map with area of larger-scale map outlined. General locality of former sea-way at Crinan is shaded, areas from which samples were collected are arrowed. Full details of collection sites are given in Table 1

are not significantly different from zero (Table 3 ). There is particularly good historical reason for anticipating genetic continuity between the "Oban" and Loch Fyne samples: the Sound of Jura and Loch Fyne were connected by a sea-way at Crinan (Fig. 1) until isostatic uplift (ca. $10000 \mathrm{yr}$ B.P.) following retreat of the ice-cap (Peacock et al. 1977). Thus there has been little time for divergence between the "Oban" and Loch Fyne OTUs.

The sampling localities in Norway, Scotland, Brittany and the western Mediterranean are on the order of 1 to $10 \times 10^{3} \mathrm{~km}$ apart. Considering the patchy distribution and limited dispersal potential of Terebratulina retusa, it may be strongly conjectured that these distant sites are effectively isolated from one another. This suggestion is supported by distribution data: $T$. retusa is absent from the Plymouth Marine Laboratory's collecting area in south-western England (Marine Biological Association 1957) and it has not been reported to us by divers searching between Cornwall and the east coast of Scotland (see 
Table 3. Terebratulina retusa. Net mtDNA divergence between population samples. Below diagonal: nucleotide difference estimates $\left(\hat{d}_{f}\right)$ derived by "fragment" procedure. Above diagonal: nucleotide difference estimates $\left(\hat{d}_{s}\right)$ derived by "sites" procedure. Standard errors are given in parentheses. Asterisks indicate nucleotide difference estimates significantly different from zero ( +2 SE). "Oban" includes data for Sound of Mull, Firth of Lorne, Luing, Insh Island
Sound of Jura (see Table 1). Effect of low DNA yields from Drobak specimens was assessed by replacing missing digests ( 1 out of $12 \mathrm{AccI}$, all of $12 \mathrm{AvaI}$ and 6 of $12 \mathrm{AvaII}$ ) with data selected (by random numbers, with replacement) from mitotypes of all 109 fully classified individuals. RESTSITE analysis indicated that missing data had no important effect on overall result; Mediterranean sample was similarly affected, but to lesser extent

\begin{tabular}{|c|c|c|c|c|c|c|}
\hline & Drobak & Isle de Batz & Loch Duich & "Oban" & Loch Fyne & Mediterranean \\
\hline Drobak & & $\begin{array}{c}0.0150 \\
(0.0136)\end{array}$ & $\begin{array}{c}0.0210 \\
(0.0164)\end{array}$ & $\begin{array}{c}0.0166 \\
(0.0155)\end{array}$ & $\begin{array}{c}0.0206 \\
(0.0164)\end{array}$ & $\begin{array}{c}0.0214 \\
(0.019)\end{array}$ \\
\hline Isle de Batz & $\begin{array}{c}0.0052 \\
(0.0054)\end{array}$ & & $\begin{array}{c}0.0015 \\
(0.0012)\end{array}$ & $\begin{array}{c}0.0004 \\
\left(^{(\text {undef.) }}\right.\end{array}$ & $\begin{array}{c}-0.0004 \\
\text { (undef.) }^{2}\end{array}$ & $\begin{array}{c}0.0024^{*} \\
(0.0010)\end{array}$ \\
\hline Loch Duich & $\begin{array}{c}0.0073 \\
(0.0065)\end{array}$ & $\begin{array}{c}0.0005 \\
(0.0004)\end{array}$ & & $\begin{array}{c}0.0039 \\
(0.0028)\end{array}$ & $\begin{array}{c}-0.0002 \\
\text { (undef.) }^{\mathrm{a}}\end{array}$ & $\begin{array}{c}0.0040^{*} \\
(0.0019)\end{array}$ \\
\hline "Oban" & $\begin{array}{c}0.0057 \\
(0.0046)\end{array}$ & $\begin{array}{c}0.0000 \\
\text { (undef.) }\end{array}$ & $\begin{array}{c}0.0013 \\
(0.0011)\end{array}$ & & $\begin{array}{c}0.0003 \\
\text { (undef.) }^{\mathrm{a}}\end{array}$ & $\begin{array}{c}0.0054^{*} \\
(0.0026)\end{array}$ \\
\hline Loch Fyne & $\begin{array}{c}0.0071 \\
(0.0071)\end{array}$ & $\begin{array}{c}-0.0002 \\
\text { (undef.) }^{\mathrm{a}}\end{array}$ & $\begin{array}{c}-0.0001 \\
\text { (undef.) }^{\mathrm{a}}\end{array}$ & $\begin{array}{l}0.0000 \\
\text { (undef.) }^{\mathrm{a}}\end{array}$ & & $\begin{array}{c}0.0021 * \\
(0.0008)\end{array}$ \\
\hline Mediterranean & $\begin{array}{c}0.0074 \\
(0.0072)\end{array}$ & $\begin{array}{c}0.0008 \\
(0.0004)\end{array}$ & $\begin{array}{c}0.0013 \\
(0.0007)\end{array}$ & $\begin{array}{c}0.0019^{*} \\
(0.0009)\end{array}$ & $\begin{array}{c}0.0007 * \\
(0.0002)\end{array}$ & \\
\hline
\end{tabular}

a Negative $\hat{d}$ values arise when mean within-population nucleotide difference is greater than between-population $\hat{d}$ value. Standard errors are then "undefined"

also Brunton and Curry 1979, their Fig. 7). Despite this apparent geographic isolation between Norway, Scotland, Brittany and the Mediterranean, only a minority of the pairwise genetic distances are significantly different from zero (Table 3). Although interpretation of these estimates is complicated by their known upward bias and the high within-population diversity (which contributes to large standard errors and reduces net between-population differences), it seems clear that there is little evidence of genetic differentiation between these populations. This conclusion is supported by the geographic distribution of mitotypes (Table 2), where the principal indication of geographic differentiation lies in the frequencies of "endemic" mitotypes, i.e., those found in only one sample. These frequencies are: Loch Duich, none out of 10; Loch Fyne, 7 of 12; "Oban" 48 of 66, Brittany, 5 of 16; Mediterranean, 5 of 5 ; i.e., there is a weak indication of endemicity in the Mediterranean sample. UPGMA cluster analysis of the $\hat{d}_{f}$ values between each pair of the 84 mitotypes, values that are not affected by within-sample diversity, confirmed this conclusion (analysis not shown). The hypothesis that there is covariance of genetic and geographic distances was also excluded by a Mantel test (Manly 1985, analysis not shown). Thus it seems that the (mitochondrial) genomes of geographically isolated populations of Terebratulina retusa from Norway to the Mediterranean are barely differentiated, contrary to expectation under the divergence hypothesis.

\section{Morphometric analysis}

Amongst the six morphometric parameters analysed on shells from six population samples, the only significant difference was in shell length between the Loch Fyne and

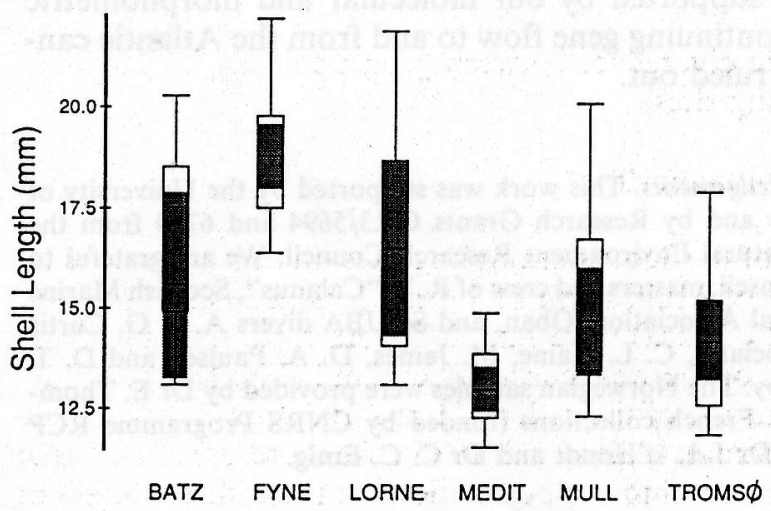

Fig. 2. Terebratulina retusa. Boxplots of shell lengths. Shaded areas indicate $95 \%$ confidence limits around median values. Numbers of shells measured: Tromsø, 17; Sound of Mull, 15; Firth of Lorne, 11; Loch Fyne, 21 Isle de Batz, 6; Mediterranean, 20

Mediterranean samples (Fig. 2). In the principal components analysis on these data, the first three axes accounted for $90.2 \%$ of the total variance and no clear betweenpopulation discrimination was found except for some separation on the first axis between the Loch Fyne and Mediterranean samples. In a previous brachiopod study, first axis discrimination was associated with size variation (McCammon and Buchsbaum 1968), corresponding to the shell-length difference shown in Fig. 2. Apart from this size difference, the populations sampled were not morphometrically distinguishable. A similar result has been obtained on many other samples (totalling over 1000 specimens) of Terebratulina retusa throughout its European range (Curry unpublished data). Thus, there is neither morphometric nor genetic evidence for cryptic speciation in the samples examined. 


\section{History of the populations sampled}

The sampled populations of Terebratulina retusa occupy sites close to or above the $200 \mathrm{~m}$ depth contour and must therefore have been established not more than $\sim 10000 \mathrm{yr}$ B.P., as the sea level rose (Milliman and Emery 1968, Morner 1982). The low between-population divergence now observed is consistent with the hypothesis that the ancestral population was large, widespread and highly diverse and that little or no genetic diversity was lost as its range extended (Avise et al. 1984). Alternatively, larvae from genetically divergent ancestral populations may have intermingled during range extension, perhaps influenced by the North Atlantic current (Curry and Endo 1991).

The suggestion that Recent Terebratulina retusa populations in the western Mediterranean were established during the $200 \mathrm{~m}$ sea-level rise is in agreement with the hydrography of the western Mediterranean (Margalef 1985) and with the affinities of other Mediterranean invertebrates (Logan 1979).

Davidson (1886-1888: footnote p. 25/26) may have accepted Mediterranean Terebratulina retusa as a distinct variety or subspecies (emarginata), whilst Logan (1979) followed Dall (1920) in rejecting this. Dall's approach is clearly supported by our molecular and morphometric data; continuing gene flow to and from the Atlantic cannot be ruled out.

Acknowledgements. This work was supported by the University of Glasgow and by Research Grants GR3/5694 and 6760 from the U.K. Natural Environment Research Council. We are grateful to Dr A. Ansell, masters and crew of R. V. "Calanus", Scottish Marine Biological Association, Oban, and SCUBA divers A. S. G. Curtis and associates, C. L. Haine, M. James, D. A. Paulsen and D. T. Ponsonby. The Norwegian samples were provided by Dr E. Thomsen, and French collections (funded by CNRS Programme RCP 728) by Dr J.-L. d'Hondt and Dr C. C. Emig.

\section{Literature cited}

Allen, J. A., Barnett, P. R. O., Boyd, J. M., Kirkwood, R. C., Mackay, D. W., Smyth, J. C. (eds.) (1986). The environment of the Estuary and Firth of Clyde. Proc. R. Soc. Edinb. (Sect B) 90: $1-539$

Avise, J. C., Bowen, B. W., Lamb, T. (1989). DNA fingerprints from hypervariable mitochondrial genotypes. Molec. Biol. Evolut. 6: 258-269

Avise, J. C., Helfman, G. S., Saunders, N. C., Hales, L. S. (1986). Mitochondrial DNA differentiation in North Atlantic eels: population genetic consequences of an unusual life history pattern. Proc. natn. Acad. Sci. U.S.A. 83: 4350-4354

Avise, J. C., Neigel, J. E., Arnold, J. (1984). Demographic influences on mitochondrial DNA lineage survivorship in animal populations. J. Molec. Evolut. 20: 99-105

Ayala, F. J., Valentine, J. W., Delaca, T. E., Zumwalt, G. S. (1975). Genetic variability of the Antarctic brachiopod Liothyrella notorcadensis and its bearing on mass extinction hypotheses. J. Paleont. 49: 1-9

Baker, C. S., Palumbi, S. R., Lambertsen, R. H., Weinrich, M. T., Calambokidis, J., O’Brien, S. J. (1990). Influence of seasonal migration on geographic distribution of mitochondrial DNA haplotypes in humpback whales. Nature, Lond. 334: 238-240
Balakirev, E. S., Manchenko, G. P. (1985). High levels of allozymic variation in brachiopod Coptothyris grayii and ascidian Halocynthia aurantium. Genetika (USSR) 21: 239-244

Brunton, C. H., Curry, G. B. (1979). British brachiopods. Synopses of the British fauna. (New Ser.) 17: 1-64

Cohen, B. L., Balfe, P., Cohen, M., Curry, G. B. (1991). Molecular evolution and morphological speciation in North Atlantic brachiopods (Terebratulina spp.). Can. J. Zool. 69: 2903-2911

Curry, G. B. (1982). Shell growth and ecology of the Recent brachiopod Terebratulina from Scotland. Palaeontology 25: 227246

Curry, G. B., Endo, K. (1991). Migration of brachiopod species in the North Atlantic in response to Holocene climatic change. Geology (Boulder, Colorado) 19: 1101-1103

Dall, W. H. (1920). Annotated list of the Recent Brachiopoda in the collection of the United States National Museum, with descriptions of thirty-three new forms. Proc. U.S. natn. Mus. 57: 261 377

Davidson, T. (1886-1888). A monograph of Recent Brachiopoda. Trans. Linn. Soc. Lond. (Ser. 2) 4: 1-247

Graves, J. E., Ferris, S. D., Dizon, A. E. (1984). Close genetic similarity of Atlantic and Pacific skipjack tuna (Katsuwonus pelamis) demonstrated with restriction endonuclease analysis of mitochondrial DNA. Mar. Biol. 79: 315-319

Jacobs, H. T. (1988). Rates of molecular evolution of nuclear and mitochondrial DNA in sea urchins. In: Burke, R. D., Mladenov, P. V., Lambert, P., Parsley, R. L. (eds.). Echinoderm biology. Balkema, Amsterdam, p. 287-295

Logan, A. (1979). The Recent Brachiopoda of the Mediterranean Sea. Bull. Inst. océanogr. Monaco 72: 1-111

Manly, B. (1985). The statistics of natural selection on animal populations. Chapman \& Hall, London

Margalef, R. (ed.) (1985). Key environments: Western Mediterranean. Pergamon Press, Oxford

Marine Biological Association, U.K. (1957). Plymouth marine fauna. 3rd edn. Marine Biological Association, Plymouth, England

McCammon, H., Buchsbaum, R. (1968). Size and shape variation of three Recent brachiopods from the Strait of Magellan. Antarctic Res. Ser. 11: 215-255

Miller, J. C. (1991). RESTSITE: a phylogenetic program that sorts raw restriction data. J. Hered. 82: 262-263

Milliman, J. D., Emery, K. O. (1968). Sea levels during the past 35000 years. Science, N. Y. 162: 1121-1123

Morner, N.-A. (1982). Sea level curves. In: Schwartz, M. C. (ed.) Encyclopaedia of beaches and coastal environments. Encylopaedia of Earth Sciences; Vol. XV. Hutchinson Ross, Stroudsburg, Pennsylvania, USA, p. 729-733

Morse, E. S. (1873). Embryology of Terebratulina. Mem. Boston Soc. nat. Hist. 2: 249-264

Nei, M. (1987). Molecular evolutionary genetics. Columbia University Press, New York

Nei, M., Li, W-H. (1979). Mathematical models for studying gene variation in terms of restriction endonucleases. Proc. natn. Acad. Sci. U.S.A. 76: 5269-5273

Nei, M., Miller, J. C. (1990). A simple method for estimating the number of nucleotide substitutions within and between populations from restriction data. Genetics, Austin, Tex. 125: 873-879

Noble, J. P. A., Logan, A., Webb, G. R. (1976). The Recent Terebratulina community in the rocky subtidal zone of the Bay of Fundy, Canada. Lethaia 9: 1-17

Peacock, J. D., Graham, D. K., Robinson, J. E., Wilkinson, I. P. (1977). Evolution and chronology of late glacial marine sediments at Lochgilphead, Scotland. In: Gray, J. M., Lowe, J. J. (eds.) Studies on the Scottish Late-glacial environment. Pergamon Press, London, p. 89-100

Reeb, C. A., Avise, J. C. (1990). A genetic discontinuity in a continuously distributed species: mitochondrial DNA in the American oyster Crassostrea virginica. Genetics, Austin, Tex. 124: 397406

Rudwick, M. J. S. (1970). Living and fossil brachiopods. Hutchinson, London 
Sokal, R. R., Michener, C. D. (1958). A statistical method for evaluating systematic relationships. Kansas Univ. Sci. Bull. 28: $1409-1438$

Valentine, J. W., Ayala, F. J. (1975). Genetic variation in Frieleia halli, a deep-sea brachiopod. Deep-Sea Res. 22: 37-44

Valentine, J. W., Jablonski, D. (1983). Larval adaptations and patterns of brachiopod diversity in space and time. Evolution 37: 1052-1061

Vawter, L., Brown, W. (1986). Nuclear and mitochondrial DNA comparisons reveal extreme rate variation in the molecular clock. Science, N. Y. 234: 194-196

Webb, G. R., Logan, A., Noble, J. P. A. (1976). Occurrence and significance of brooded larvae in a Recent brachiopod, Bay of Fundy, Canada. J. Paleont. 50: 869-871
Wilson, A. C., Cann, R. L., Carr, S. M., George, M., Gyllensten, U. B., Helm-Bychowski, K., Higuchi, R. G., Palumbi, S. R., Prager, E. M., Sage, R. D., Stoneking, M. (1985). Mitochondrial DNA and two perspectives on evolutionary genetics. Biol. J. Linn. Soc. 26: 375-400

Wirgin, I. I., Proenca, R., Grossfield, J. (1989). Mitochondrial DNA diversity among populations of striped bass in the southeastern United States. Can. J. Zool. 67: 891-907

Communicated by J. Mauchline, Oban 